Pace University

DigitalCommons@Pace

6-7-2011

\title{
Arbitration Case Law Update 2011
}

Jill I. Gross

Pace Law School

Follow this and additional works at: https://digitalcommons.pace.edu/lawfaculty

Part of the Dispute Resolution and Arbitration Commons, and the Securities Law Commons

\section{Recommended Citation}

Jill I. Gross \& Christopher Bloch, Arbitration Case Law Update 2011, in Securities Arbitration 2011 (PLI Course Handbook, June 7, 2011), http://digitalcommons.pace.edu/lawfaculty/1042.

This Book Chapter is brought to you for free and open access by the School of Law at DigitalCommons@Pace. It has been accepted for inclusion in Pace Law Faculty Publications by an authorized administrator of DigitalCommons@Pace. For more information, please contact dheller2@law.pace.edu. 


\title{
Arbitration Case Law Update 2011
}

By

\author{
Jill I. Gross
}

Professor of Law, Director of Legal Skills

Director, Investor Rights Clinic, Pace Law School

and

Christopher Bloch

Law Graduate Assistant, Pace Investor Rights Clinic

Research Scholar, Institute of International Commercial Law,

Pace Law School

June 7, 2011 
Parties to arbitration agreements sometimes invoke the judicial system to litigate collateral issues arising out of the arbitration process, such as arbitrability of some or all of the claims, arbitrator bias, and award enforcement or vacatur. When deciding these collateral issues arising out of securities arbitration, courts interpret and apply the Federal Arbitration Act, 9 U.S.C. $\S \S$ 1 et seq. (2010) ("FAA"). ${ }^{1}$ In this chapter, we identify recent judicial decisions in the area of arbitration law, and analyze their impact on securities arbitration practice.

\section{U.S. Supreme Court}

Since the PLI Arbitration Law Update 2010 was published last June, the United States Supreme Court has remained very active in the area of arbitration law, issuing two opinions interpreting the FAA, and granting certiorari on two additional cases involving two different defenses to arbitrability (waiver and public policy).

\section{A. Who Decides Arbitrability?}

The Supreme Court has observed that the question of "who - court or arbitrator - has the primary authority to decide whether a party has agreed to arbitrate can make a critical difference to a party resisting arbitration." ${ }^{2}$ Although the Court has held repeatedly "that questions of arbitrability must be addressed with a healthy regard for the federal policy favoring arbitration," it has reversed that presumption on the question of "who decides" questions of arbitrability. Thus, courts decide substantive

\footnotetext{
${ }^{1}$ Because securities arbitration necessarily "involves commerce" (FAA $\S$ 2 (2010)), it is deemed under the auspices of the FAA. See Howsam v. Dean Witter Reynolds, Inc., 537 U.S. 79 (2002).

${ }^{2}$ First Options of Chicago, Inc. v. Kaplan, 514 U.S. 938, 942 (1995).

${ }^{3}$ See, e.g., Mitsubishi Motors Corp. v. Soler Chrysler-Plymouth, Inc., 473 U.S. 614, 626 (1985).
} 
arbitrability, or "gateway" issues that parties would likely expect a court to determine, such as the validity of an arbitration agreement itself or the breadth of an arbitration agreement, unless there is evidence of the "clear and unmistakable" intention of the parties to have arbitrators decide that issue. ${ }^{4}$ In contrast, arbitrators decide questions of procedural arbitrability: those issues "which grow out of the dispute and bear on its final disposition."

The Court found such "clear and unmistakable" evidence in a decision it handed down at the end of its 2009-10 term. In Rent-A-Center, Inc. v. Jackson, ${ }^{6}$ a 5-4 decision authored by Justice Scalia and joined by Justices Roberts, Kennedy, Thomas and Alito, the Court held that an arbitration agreement may validly delegate to the arbitrators the power to decide a challenge to arbitrability on the grounds of unconscionability, unless the unconscionability challenge focuses specifically on the delegation provision.

Respondent Antonio Jackson filed an employment discrimination suit under 42 U.S.C. § 1982 in federal district court in Nevada against his employer, petitioner Rent-A-Center. As a condition of employment, Rent-A-Center had required Jackson to sign a "Mutual Agreement to Arbitrate Claims" ("Agreement") which provided, in relevant part, "for arbitration of all 'past, present or future' disputes arising out of Jackson's employment with Rent-A-Center, including 'claims for discrimination' and "claims for violation of any federal . . law.",7 The Agreement explicitly stated that " $[t]$ he Arbitrator, and not any federal, state, or

\footnotetext{
${ }^{4}$ See First Options, 514 U.S. at $944-45$.

${ }^{5}$ See, e.g., Howsam, 537 U.S. at 84 (citation and internal quotation omitted) (holding that a federal district court should not interpret the NASD six-year eligibility rule because the decision is presumptively reserved for the arbitrator).

${ }^{6} 130$ S. Ct. 2772 (2010).

${ }^{7} I d$. at 2775 .
} 
local court or agency, shall have exclusive authority to resolve any dispute relating to the interpretation, applicability, enforceability or formation of this Agreement including, but not limited to any claim that all or any part of this Agreement is void or voidable."

Invoking the Agreement in district court, Rent-A-Center moved for an order compelling arbitration of the employment dispute. Jackson opposed the motion, asserting that the Agreement was unenforceable as unconscionable under Nevada law because it contained an unfavorable fee-sharing arrangement. ${ }^{9}$ The district court found that the Agreement clearly and unmistakably delegated to the arbitrator the exclusive authority to determine its enforceability, even in the face of an unconscionability challenge. ${ }^{10}$

On appeal, the Ninth Circuit reversed. The Court of Appeals held that, when "a party challenges an arbitration agreement as unconscionable, and thus asserts that he could not meaningfully assent to the agreement, the threshold question of unconscionability is for the court." 11

The Supreme Court reversed the Ninth Circuit, holding that parties may - by agreement - delegate to the arbitrators a question of arbitrability. The Court acknowledged that the FAA "places arbitration agreements on an equal footing with other contracts," and requires courts to enforce their terms subject only to general contract defenses. ${ }^{12}$ The FAA operates on "an additional, antecedent agreement" that delegates to the arbitrators

${ }^{8} I d$.

${ }^{9} \mathrm{Id}$.

${ }^{10} I d$. The district court added that it would have rejected the unconscionability challenge even if the Agreement had not delegated that question to the arbitrators for decision. Id. at 2776.

${ }^{11}$ Jackson v. Rent-A-Center West, Inc., 581 F.3d 912, 917 (9th Cir. 2009) (remanding to the district court to determine whether the Agreement was unconscionable on grounds other than the fee-sharing arrangement).

${ }^{12} 130$ S. Ct. at 2776. 
the authority to decide a "gateway" issue "just as it does on any other."13

In addition, Jackson had not challenged the delegation provision of the Agreement specifically, but rather "opposed the motion to compel on the ground that the entire arbitration agreement, including the delegation clause, was unconscionable." " Thus, the Court held that the arbitrator, and not the courts, had the authority to consider Jackson's unconscionability challenge.

The Supreme Court's decisions under the FAA reflect the tension between freedom of contract and arbitrator accountability. In Jackson, the Court reinforced its commitment to enforcing the terms of an arbitration agreement that demonstrate the "clear and unmistakable" intentions of the parties, regardless of how much power is ceded to the arbitrators.

\section{B. FAA Preemption}

Another consistent holding in the Supreme Court's FAA jurisprudence is that FAA $\$ 2$ - which declares that agreements to arbitrate are "valid, irrevocable, and enforceable, save upon such grounds as exist at law or in equity for the revocation of any contract" $" 15$ - preempts state laws that place an arbitration agreement on unequal footing from other contracts. ${ }^{16}$ Where a state law prohibits the arbitration of a particular type of claim, courts can more readily find FAA preemption. However, courts have struggled where a generally applicable contract defense, such

${ }^{13}$ Id. at $2777-78$.

${ }^{14}$ Id. at 2779 .

159 U.S.C. \$2. The latter phrase of this section is known as the FAA's "savings clause."

${ }^{16}$ See, e.g., Doctor's Assocs., Inc. v. Casarotto, 517 U.S. 681, 685 (1996). 
as unconscionability, was arguably being applied in a manner that was de facto disfavoring arbitration.

The Court faced this question in its second arbitration law decision in the past year. In $\boldsymbol{A T} \& \boldsymbol{T}$ Mobility, LLC $\boldsymbol{v}$. Concepcion, the Court ruled that the FAA preempts California's Discover Bank rule, which "classif[ied] most collective-arbitration waivers in consumer contracts as unconscionable."17

In its consumer cellular phone service contracts, AT\&T Mobility, LLC (“AT\&T") included a pre-dispute arbitration agreement which, inter alia, prohibited plaintiffs from bringing class action arbitrations, instead requiring claims to be arbitrated on an individual basis. In 2006, the Concepcions sued AT\&T in district court, alleging that AT\&T's practice of charging sales tax on a phone advertised as "free" was fraudulent. ${ }^{18}$ In December 2006, after the Concepcions filed their claim, AT\&T revised the arbitration agreement to provide that AT\&T would pay a customer $\$ 7,500$ if an arbitrator found in favor of a California customer on the merits of a customer dispute, and awarded more than the last AT\&T settlement offer. ${ }^{19}$ Two years later, after the Concepcions' case was consolidated with a putative class action alleging, inter alia, identical claims of false advertising and fraud, AT\&T moved to compel arbitration under the revised agreement. ${ }^{20}$

The district court refused to enforce the arbitration agreement under FAA §2's savings clause. The court concluded that the class action waiver of the arbitration agreement was unconscionable because it had a deterrent effect on class actions

17131 S. Ct. 1740 (Apr. 27, 2011).

${ }^{18}$ Laster v. AT\&T Mobility, LLC, 584 F.3d 849, 853 (9th Cir. 2009). Concepcion was consolidated with Laster in September 2006.

${ }^{19}$ Id.

${ }^{20} I d$. 
and the efficient resolution of third party claims. ${ }^{21}$ After the Ninth Circuit affirmed, on an interlocutory appeal, the district court's conclusion that the class-arbitration waiver was unconscionable and that the FAA did not preempt the Discover Bank rule, ${ }^{22}$ AT\&T sought review in the Supreme Court.

On April 27, 2011, the Supreme Court, in a 5-4 decision, in which Justice Scalia (joined by Justices Roberts, Kennedy, and Alito) authored a plurality opinion and Justice Thomas authored a concurring opinion, held that the FAA preempts California's Discover Bank interpretation of the state's unconscionability rule. The Court concluded that the Discover Bank rule created a different law of unconscionability for class action waivers in adhesive arbitration contracts. ${ }^{23}$ Thus, the FAA preempts the rule, as it singles out arbitration clauses for suspect treatment. ${ }^{24}$

${ }^{21} I d$

${ }^{22} I d$. at $853-55,856-69$.

${ }^{23}$ The Supreme Court noted that, under California law, a court may refuse to enforce a contract that it finds " "to have been unconscionable at the time it was made," "or it may " "limit the application of any unconscionable clause,"” 131 S. Ct. at 1746 (quoting Cal. Civ. Code Ann. $\S 1670.5(1)$ (1985)). "A finding of unconscionability requires a 'procedural' and a 'substantive' element, the former focusing on 'oppression' or 'surprise' due to unequal bargaining power, the latter on 'overly harsh' or 'one-sided' results." $131 \mathrm{~S}$. Ct. at 1746 (citations omitted). In Discover Bank v. Superior Court, 36 Cal. 4th 148 (Cal. 2005), the California Supreme Court applied this unconscionability law to class-action waivers in arbitration agreements and held:

[W] hen the waiver is found in a consumer contract of adhesion in a setting in which disputes between the contracting parties predictably involve small amounts of damages, and when it is alleged that the party with the superior bargaining power has carried out a scheme to deliberately cheat large numbers of consumers out of individually small sums of money, then ... the waiver becomes in practice the exemption of the party "from responsibility for [its] own fraud, or willful injury to the person or property 
The Court rejected the Concepcions' argument that the Court should defer to the California Supreme Court's analysis of its own unconscionability doctrine and instead use an objective determination on whether or not the rule is "tantamount to a rule of non-enforceability of arbitration agreements." ${ }^{25}$ Rather, the plurality was persuaded by research which demonstrated that state courts had become more likely to find an arbitration agreement unconscionable as opposed to other contracts. ${ }^{26}$ The plurality also noted that, although California's "rule does not require class-wide arbitration, it allows any party to a consumer contract to demand it ex post," thus defeating the purposes of the FAA. ${ }^{27}$

of another." Under these circumstances, such waivers are unconscionable under California law and should not be enforced.

Id. at $162-63$.

${ }^{24}$ AT\&T identified three principles from Discover Bank that it contended courts applied differently to arbitration agreements than to other contracts: (1) the effect on third parties; (2) the timing of the unconscionability decisions; and (3) the shock the conscience standard. Transcript of Oral Argument at 12, AT\&T v. Concepcion, 131 S. Ct. 1740 (2011).

${ }^{25} I d$. at 39.

${ }^{26}$ Concepcion, $131 \mathrm{~S}$. Ct. at 1747.

${ }^{27}$ Id. at 1750. The Court discussed three characteristics of class arbitration that it concluded defeat the purposes of the FAA and hinder the flexible party-driven process of arbitration: (1) sacrifice of informality and speed; (2) a requisite increase in procedural formality; and (3) an increase in risks to defendants in the lack of judicial review. Id. at 175152. Although the plurality expressly included the procedural expediency of arbitration as one of the FAA's purposes with which the Discover Bank rule interferes, the dissent referred to the Court's Dean Witter decision in which it specifically "reject[s] the suggestion that the overriding goal of the [FAA] was to promote the expeditious resolution of claims." Id. at 1758 (Breyer, J., dissenting) (citing Dean Witter Reynolds Inc. v. Byrd, 470 U.S. 213, 221 (1985)). 
Justice Scalia's plurality opinion was fueled by a singular distrust of class arbitration, a distrust that also appeared in the Court's 2010 decision in Stolt-Nielsen S.A. v. AnimalFeeds Int'l Corp. $^{28}$ In contrast, the dissent claimed that class proceedings are necessary to protect against small-value claims falling through the cracks of the legal system. ${ }^{29}$ Justice Scalia responded to the dissent's concern by stating that "States cannot require a procedure that is inconsistent with the FAA, even if it is desirable for unrelated reasons." 30

Justice Thomas agreed with the result, but on slightly different grounds. In his concurring opinion, Justice Thomas reasoned that the savings clause of the FAA permits exceptions to the enforceability of arbitration agreements only for defenses that "relate[] to the making of the [arbitration] agreement."31 Because the Discover Bank rule did not relate to the making of the arbitration agreement within the meaning of FAA $\S \S 2$ and 4, Justice Thomas concluded that it is preempted by the FAA. While Justice Thomas' interpretation of FAA $\$ 2$ differed from prior Supreme Court jurisprudence, and was not briefed or advocated by the parties, his vote was necessary for the 5-4 reversal. Thus, his opinion, which arguably rests on narrower grounds than the plurality's, may be considered controlling for future cases.

There seems to be little doubt that this decision will have an adverse impact on consumer arbitration, as it effectively eliminates class arbitration as a procedural method of aggregating low value claims that are subject to an otherwise enforceable arbitration agreement. However, if courts construe the decision more narrowly as preempting only California's "Discover Bank rule," rather than unconscionability rules nationally, the decision

${ }^{28} 130$ S. Ct. 1758 (2010).

${ }^{29}$ Id. at 1760-61 (Breyer, J., dissenting).

${ }^{30} \mathrm{Id}$. at 1753 .

${ }^{31} I d$. at 1754-55 (Thomas, J., concurring) (quoting FAA § 4). 
won't have quite the broad-reaching impact predicted by some commentators. ${ }^{32}$ In the end, Congressional action may be the only way to preserve class arbitration.

\section{Waiver}

While federal courts tout the strong national policy favoring arbitration and the enforcement of arbitration agreements, they disfavor disputants who appear to be using that national policy to manipulate the court system and prejudice adverse parties. In recent years, they have embraced the waiver defense a claim that one party to an arbitration clause has waived its right to arbitrate based on conduct in parallel litigation. As discussed below, the Supreme Court appears headed to decide the scope of the waiver defense next term.

Courts generally find a party has waived its right to arbitration "when it engages in protracted litigation that prejudices the opposing party." ${ }^{33}$ While the waiver test varies slightly among the federal circuits, courts typically consider factors such as: (1) the time elapsed from commencement of litigation to the request for arbitration; (2) the amount and nature of litigation, including

\footnotetext{
${ }^{32}$ See, e.g., Sarah Cole, "Continuing the Discussion of the AT\&T v. Concepcion Decision: Implications for the Future," posting to ADR Prof Blog, http://www. indisputably.org/?p=2312 (Apr. 27, 2011) ("It would appear that the era of class arbitration is over before it really ever began unless Congress can be persuaded to amend the FAA to permit class arbitration, at least in cases involving low value claims, where consumers are unlikely to have practical recourse to a remedy through traditional bilateral arbitration"); Marcia Coyle, Divided Justices Back Mandatory Arbitration for Consumer Complaints, N.Y.L.J., Apr. 28, 2011 (quoting lawyer for Concepcions as stating "' $[\mathrm{t}]$ he decision will make it harder for people with civil rights, labor, consumer and other kinds of claims that stem from corporate wrongdoing to join together to obtain their rightful compensation"').

${ }^{33}$ Nat'l Union Fire Ins. Co. of Pittsburgh, P.A. v. NCR Corp., No. 092904-cv, 2010 U.S. App. LEXIS 9358, at *2 (2d Cir. May 7, 2010).
} 
substantive motions and discovery; and (3) prejudice to the party opposing arbitration. ${ }^{34}$ Prejudice "refers to the inherent unfairness - in terms of delay, expense or damage to a party's legal position that occurs when the party's opponent forces it to litigate an issue and later seeks to arbitrate that same issue." ${ }^{\prime 35}$

A recent case involving a FINRA member firm illustrates the lower courts' approach to the waiver defense. In Louisiana Stadium Exposition District v. Merrill Lynch, ${ }^{36}$ the Second Circuit refused to reverse the district court's denial of a motion to compel arbitration on the ground that plaintiff Louisiana Stadium Exposition District ("LSED") had waived its right to enforce the pre-dispute arbitration clause. LSED initiated identical proceedings in Louisiana state court and the U.S. District Court for the Eastern District of Louisiana against Financial Guaranty Insurance Company, and, shortly thereafter, added claims against three separate Merrill Lynch entities, including Merrill Lynch, Pierce, Fenner \& Smith, Inc. ("MLPFS"), the ultimate sole defendant. Eleven months after these filings, LSED moved to compel arbitration against MLPFS. ${ }^{37}$

The court considered the three National Union factors in its waiver analysis. While acknowledging that no factor by itself is dispositive in finding waiver, the court specifically singled out the

\footnotetext{
${ }^{34}$ See Id.

${ }^{35}$ Id. (citing In re Crysen/Montenay Energy Co., 226 F.3d 160, 162-63 (2d Cir. 2000) (internal quotation omitted)).

${ }^{36} 626$ F.3d 156 (2d Cir. 2010).

${ }^{37}$ During that eleven-month time period, defendants (1) filed a motion to remove the state court action to federal court; (2) filed a motion to transfer the case to the Southern District of New York; (3) moved to stay the proceedings in Louisiana federal court pending the decision of a Multidistrict Litigation Panel to centralize in one district four related cases pending against defendants in other districts; (4) submitted to LSED a nineteen-page letter identifying all the perceived deficiencies in the second amended complaint; (5) filed an answer to the third amended complaint; and (6) began work on a motion to dismiss. Id. at 159.
} 
third factor, proof of prejudice, as the "key to a waiver analysis." 38 The Second Circuit found both procedural and substantive prejudice caused by LSED's delay in moving to compel arbitration. Procedurally, in addition to MLPFS's spending of significant resources in its motion practice to date, the court found that LSED had only pursued arbitration after MLPFS had submitted a detailed letter addressing perceived deficiencies in LSED's second amended complaint, and again, only after LSED had unsuccessfully attempted to defeat the motion to transfer the case to the Southern District of New York.

Substantively, the court found that MLPFS would be prejudiced by the preemption of consideration on the "inevitable motion for judgment on the pleadings which was plainly foreshadowed by the detailed deficiency letter." 39 In short, by waiting for MLPFS to submit answers to LSED's amended complaints and receive the detailed deficiency letter, LSED obtained significant benefit which would not have been available in an arbitration proceeding. By denying LSED's motion to compel arbitration, the Second Circuit reinforced its reluctance to allow litigants to invoke arbitration clauses only after litigation has not gone their way.

Not surprisingly, in light of the increase in waiver cases surrounding arbitration, the Supreme Court granted certiorari this term to consider - for the first time - the scope of the waiver defense. In Stok \& Associates, P.A. v. Citibank, N.A, ${ }^{40}$ the Court agreed to consider whether, under the FAA, prejudice is a required element of the waiver defense. In the opinion below, the Eleventh Circuit Court of Appeals reversed the district court's finding that

\footnotetext{
${ }^{38} I d$.

${ }^{39} I d$. at 160.

${ }^{40} 131$ S. Ct. 1556 (2011).
} 
Citibank had waived its right to arbitrate a claim brought by Stok \& Associates, P.A. ${ }^{41}$

Stok is a law firm that had deposited a large check from a client into its Citibank bank account. ${ }^{42}$ Citibank discovered the check was actually a forgery and removed the funds from Stok's account. ${ }^{43}$ A dispute arose concerning Citibank's actions, and Stok filed a complaint in Florida state court alleging various state law causes of action. ${ }^{44}$ About six weeks later, Citibank answered the complaint without reference to the pre-dispute arbitration clause in the bank's customer agreement with Stok. ${ }^{45}$ Within a few weeks, Stok served an offer of judgment and a discovery request on Citibank, and filed a reply to the answer and a notice of readiness with the state court. ${ }^{46}$ Less than one month after it filed its answer, Citibank sent a letter to Stok electing arbitration, which Stok rejected. ${ }^{47}$ The next day, Citibank filed a motion to compel arbitration in state court, but then withdrew that motion and instead filed a petition to compel arbitration in federal district court for the Southern District of Florida. ${ }^{48}$ The state court then stayed discovery for 60 days in the pending resolution of the federal court action, and removed the case from the trial docket. ${ }^{49}$

The federal district court denied Citibank's petition to compel arbitration on the ground advanced by Stok - that Citibank had waived its right to elect arbitration because of its participation

${ }^{41}$ Citibank, N.A. v. Stok \& Associates, P.A., 387 Fed. Appx. 921 (11th Cir. 2010), cert. granted, 131 S. Ct. 1556 (2011).

${ }^{42}$ Id. at 922 .

${ }^{43} I d$.

${ }^{44} \mathrm{Id}$.

${ }^{45} I d$.

${ }^{46} I d$. at .

${ }^{47}$ Id. at $922-23$.

${ }^{48}$ Id. at 923 .

${ }^{49}$ Id. 
in the state court action. ${ }^{50}$ In its decision, the district court applied the Eleventh Circuit's two-prong waiver test, which required the movant to show the waiving party acted inconsistently with its right to arbitration and its actions prejudiced the moving party. Citibank appealed. ${ }^{51}$ The Eleventh Circuit reversed on the ground that, even if Stok met its burden of showing that Citibank acted inconsistently with its right to arbitration, it had not demonstrated that Citibank's conduct prejudiced Stok. ${ }^{52}$

Stok then sought review in the Supreme Court, arguing that there is a conflict among the circuits as to whether prejudice is a necessary element of the arbitration waiver analysis. ${ }^{53}$ Stok argued that a majority of circuits (nine) required a showing of prejudice, and a minority of circuits (three) did not. ${ }^{54}$ Stok also argued that the Court should rule that no showing of prejudice should be required, as such a requirement violates long-standing principles of common law contract. ${ }^{55}$ Citibank filed a very brief opposition (five pages) to the Petition, arguing only that there was no conflict in the circuits, as even the three circuits that did not explicitly include prejudice as a prong of its formal waiver test did consider prejudice as one factor in the overall analysis. ${ }^{56}$

Since the Supreme Court granted certiorari, it appears the Court concluded that the circuits were indeed split on this issue. Thus, the issue is quite simple and clearly crystallized before the Court: Should courts require a showing of prejudice before concluding that a party has waived its right to arbitration?

\footnotetext{
${ }^{50} I d$.

${ }^{51} I d$. at 924.

${ }^{52}$ Id. at $924-25$.

${ }^{53}$ Petition for Writ of Certiorari, Stok \& Assocs. P.A. v. Citibank, N.A., 2010 WL 4090959, *6-7 (Oct. 14, 2010).

${ }^{54} I d$., *7-14.

${ }^{55}$ Id., *15-31.

${ }^{56}$ See generally Brief Opposing Writ of Certiorari, Stok \& Assocs. P.A. v. Citibank N.A., 2011 WL 63537 (Jan. 5, 2011).
} 
Why did the Court take this case? The circuit courts themselves have not acknowledged that a conflict exists among them on the waiver question. Moreover, the Court's FAA jurisprudence instructs lower courts to resolve questions of arbitrability in favor of arbitration - which would suggest requiring the party resisting arbitration to make a strong showing before finding that a party seeking arbitration had waived its right to arbitration. This strong showing presumably would stem from, in part, prejudice to the party opposing arbitration. Third, the facts in this case do not cry out for a finding of prejudice. As the Eleventh Circuit noted in its opinion, courts that have found prejudice to the party opposing arbitration were faced with far more compelling facts: litigation activities for several years, rather than the few weeks present in Stok; and motion practice and extensive discovery requiring the party opposing arbitration to incur substantial legal fees and other litigation costs, unlike the relatively brief reply to answer and other litigation documents that Stok filed and served in the intervening weeks in this case. Thus, even if the Court were to conclude that prejudice is a requirement before finding an arbitration waiver, no prejudice was present here, as the circuit court concluded.

On the other hand, if the Court rules that prejudice is not required, this is not a case that plainly calls out for application of the waiver doctrine, as Citibank's conduct in the five-week time period at issue was arguably not even inconsistent with its right to arbitration. Finally, Citibank, a national banking institution with substantial litigation resources, barely opposed Stok's certiorari petition, suggesting even Citibank did not think the issues on appeal were ripe for Supreme Court intervention.

Finally, even if the Supreme Court affirms the Eleventh Circuit and retains the prejudice prong of the waiver test, the Eleventh Circuit had remanded the case to the district court for 
consideration of Stok's other arbitrability arguments opposing the motion to compel arbitration. Thus, victory in the Supreme Court would not result in an automatic grant of Citibank's petition to compel arbitration. It would only ensure a date back in district court for consideration of Stok's other arguments opposing the petition.

\section{Arbitrability of Federal Statutory Claim}

Since its watershed decision in Shearson/American Express Inc. v. McMahon ${ }^{57}$ that federal securities law claim are arbitrable, the Supreme Court has held consistently that plaintiffs could vindicate their rights arising under federal statutes in arbitration, and thus federal statutory claims were arbitrable as a matter of public policy. In CompuCredit Corp. v. Greenwood ${ }^{58}$ the Court accepted a second arbitration case for next term, and agreed to resolve a circuit split on the question of whether claims arising under the Credit Repair Organizations Act, 15 U.S.C. $\S$ 1679 et seq.("CROA"), are arbitrable.

The Ninth Circuit had decided in the opinion below that Congress intended to preclude arbitration of claims arising under the CROA, a consumer protection statute, when it provided consumers with a "right to sue" violators of the prohibitions in the statute. ${ }^{59}$ Because that Ninth Circuit decision conflicted with opinions from the Third and Eleventh Circuits, the Supreme Court granted a petition for a writ of certiorari to resolve the circuit split.

What is notable is that many claims arising under the CROA are pursued in class actions, as they typically are too small for consumers to bring them individually. Since the Court this

\footnotetext{
${ }^{57} 482$ U.S. 220 (1987).

5879 U.S.L.W. 3442, 2011 U.S. LEXIS 3404 (May 2, 2011).

${ }^{59}$ Greenwood v. CompuCredit Corp., 615 F.3d 1204, 1206-07 (9th Cir. 2010).
} 
term effectively eliminated class arbitration of consumer protection claims in Concepcion, the stakes are quite high for consumers. A decision to reverse the Ninth Circuit holding that CROA claims are arbitrable could eliminate the ability of many consumers to vindicate their CROA statutory rights.

\section{Notable Lower Federal Court Decisions}

\section{A. Challenges to Arbitrability}

\section{Was there an enforceable arbitration agreement?}

Before a court can grant a motion to compel arbitration under the FAA, it must be satisfied that the disputing parties entered into a valid and enforceable arbitration agreement. In Janiga v. Questar Capital Corp. ${ }^{60}$ the Seventh Circuit Court of Appeals considered whether a brokerage firm customer's alleged limited understanding of the English language precluded a "meeting of the minds" with respect to the customer agreement which contained the pre-dispute arbitration clause. Plaintiff Alfred Janiga, a Polish immigrant, sued his broker, Weislaw Hessek, a registered representative of Questar Capital (who also happened to be Janiga's brother), Hessek's financial services company, and Questar Capital in federal district court in Illinois to recover investment losses. Questar moved to compel arbitration, but Janiga resisted on the ground that, inter alia, he did not understand the customer agreement and saw only one page of it. ${ }^{61}$ While the Court of Appeals acknowledged Janiga's contention that all of his communications with Hessek were in Polish, the court also remarked that Janiga had lived and worked in Illinois for more

${ }^{60} 615$ F.3d 735 ( $7^{\text {th }}$ Cir. 2010).

${ }^{61} I d$. at 739 . 
than twenty years and was a principal of a company specializing in residential and commercial remodeling. ${ }^{62}$

The Seventh Circuit found that a valid arbitration clause existed, reasoning that Janiga's signature on the customer account agreement, which he admitted he gave voluntarily, "objectively demonstrated his assent to the contract." "unambiguous" arbitration clause was in all capital letters, just above Janiga's signature. ${ }^{64}$ Thus, Janiga entered into a valid arbitration agreement with Questar.

Investors whose primary language is not English beware: the Court of Appeals' lack of sympathy, and perhaps even disdain, for Janiga's alleged limited understanding of English is palpable in the opinion. At least according to this decision, investors who sign a customer agreement, whether or not they can show they are capable of understanding it, are bound to its terms.

\section{Who is a "customer" under FINRA Rule 12200?}

In a FINRA customer-initiated arbitration, respondents may resist arbitration on the ground that the claimant is not a "customer" of the FINRA member firm within the meaning of FINRA Code of Arbitration Procedure for Customer Disputes Rule 12200. That rule provides that a FINRA member firm must arbitrate a claim if "requested by a customer," "[t]he dispute is between a customer and a member or associated person of a member; and [t]he dispute arises in connection with the business activities of the member or the associated person . ...,65

\footnotetext{
${ }^{62}$ Id. at $737-38$.

${ }^{63} \mathrm{Id}$. at 743 .

${ }^{64}$ Id.

${ }^{65}$ FINRA R. 12200.
} 
The Second Circuit recently contributed to the growing body of circuit court opinions interpreting FINRA Rule 12200. In UBS Securities, LLC v. Voegeli, ${ }^{66}$ the Second Circuit affirmed the district court's issuance of a permanent injunction prohibiting Swiss investors from arbitrating securities fraud claims against UBS Securities, Inc. Defendants were Swiss citizens who were seed investors in HealtheTech, Inc., a company for which UBS acted as a financial advisor and underwriter in its initial public offering. ${ }^{67}$ When HealtheTech's post-IPO stock value declined, the Swiss investors filed an arbitration claim against UBS alleging, inter alia, securities fraud. ${ }^{6}$

A FINRA arbitration panel rejected UBS' claim that the Swiss investors, who did not purchase their HealtheTech securities through a brokerage account at UBS, were not its "customers," and declined to halt the arbitration. ${ }^{69}$ UBS then sought injunctive relief in the district court for the Southern District of New York, on the grounds that defendants had never been "customers" of UBS, as required by FINRA Rule $12200 .^{70}$ The district court issued a permanent injunction, finding both irreparable harm and success on the merits. ${ }^{71}$ The district court noted that parties will not become "customers" under FINRA's Code of Arbitration Procedure merely because they were shareholders of a company that a broker-dealer advised in connection with an IPO. ${ }^{72}$

The Second Circuit affirmed the issuance of the injunction, agreeing with the district court that the Swiss investors were not customers of UBS nor did they have a contract requiring

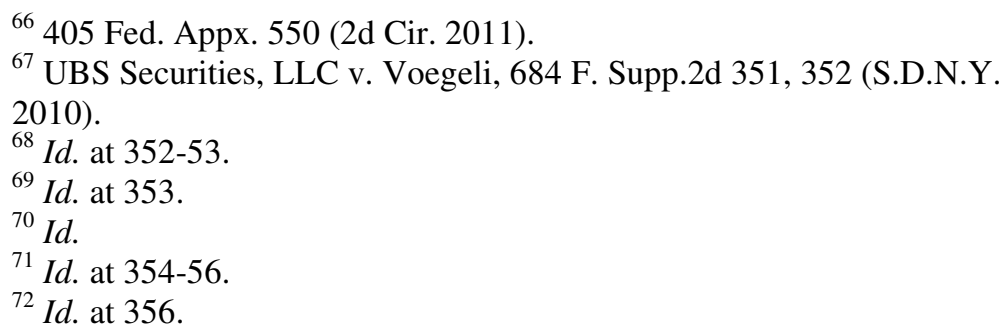


arbitration. ${ }^{73}$ The Court of Appeals also affirmed the district court's conclusion that "[b]eing forced to arbitrate a claim one did not agree to arbitrate constitutes an irreparable harm for which there is no adequate remedy at law." 74

\section{Are "collective actions" arbitrable under}

\section{FINRA Rule 12204/13204?}

A federal district court in the Southern District of New York, in Velez v. Perrin Holden \& Davenport Capital Corp. ${ }^{75}$ addressed the issue of whether the class arbitration ban under FINRA's Code of Arbitration Procedure extends to collective actions. Silva Alexander Velez, an employee of FINRA member Perrin Holden \& Davenport Capital Corp. ("Perrin"), sued Perrin alleging violations of the Fair Labor Standards Act ("FLSA") and New York's Labor Law on behalf of himself and similarly situated brokers employed or formerly employed by Perrin. Velez asked the district court to designate the suit as a "collective action" under the FLSA, and to designate his state law claims as a class action.

Perrin subsequently moved to dismiss the action, or alternatively, to compel FINRA arbitration of the FLSA claims under FAA $\S 3$ and pursuant to the arbitration clause in the “Account Executive At-Will Employment Agreement." Although Perrin could not seek arbitration of the state law claims, because FINRA Rule 13204 explicitly prohibits the arbitration of "class action claims," Perrin argued that collective actions are separate and distinct from class action claims, and thus the FLSA claims were arbitrable. Velez contended that FINRA Rule 13204 should be interpreted to encompass collective actions as well as class action claims.

\footnotetext{
73405 Fed. Appx. at 552.

${ }^{74}$ Id. (citing Merrill Lynch Inv. Managers v. Optibase, Ltd., 337 F.3d 125, 129 (2d Cir. 2003)).

7510 Civ. 3735, 2011 U.S. Dist. LEXIS 16678 (S.D.N.Y. Feb. 3, 2011)
} 
Following other district courts that have considered the issue ${ }^{76}$ the Velez court ruled that collective actions should be considered separate and distinct from class action claims. Although class actions and collective actions share similar characteristics, the court focused on one, and, in its opinion, significant, difference - the fact that class actions are opt-out actions while collective actions are opt-in actions. ${ }^{77}$ In an opt-out action, each member of the class must affirmatively act to remove himself from the action, but in an opt-in action, the members of the class must act in order to participate in the action. Thus, in a collective action, the decision will "bind only similarly situated plaintiffs who have affirmatively consented to join the action." ${ }^{, 78}$ As a result, the district court compelled arbitration of plaintiffs' FLSA claims.

Notably, the court rejected opinion letters from FINRA staff members (including an Assistant General Counsel and the Director of Arbitration) construing collective actions as within the meaning of Rule $12304 .^{79}$ The court refused to take those letters into account because FINRA - as well as the authors themselves indicated that staff opinions are merely that - the personal opinions of those staff members who work for FINRA, and they do not bind FINRA or its Board. The court noted that, if FINRA intends to prohibit collective actions, it may do so by amending its rules.

The court's refusal to give deference to FINRA staff opinion letters construing FINRA's own Code of Arbitration

${ }^{76}$ See Gomez v. Brill Securities, Inc., No. 10 Civ. 3503, 2010 U.S. Dist. LEXIS 118162 (S.D.N.Y. Nov. 2, 2010); Suschil v. Ameriprise Financial Servs., Inc., No. 07 Civ. 2655, 2008 U.S. Dist. LEXIS 27903 (N.D. Ohio Apr. 7, 2008); Chapman v. Lehman Bros., Inc. 279 F. Supp.2d 1286 (S.D. Fla. 2003).

${ }_{77}^{7}$ Velez, 2011 U.S. Dist. LEXIS 16678, *6.

${ }^{78} \mathrm{Id}$.

${ }^{79}$ Id. 
Procedure seems peculiar. If the Supreme Court defers to FINRA arbitrators to construe FINRA's eligibility rule, ${ }^{80}$ then why shouldn't a federal district court defer to FINRA's Director of Arbitration to construe FINRA Rules 12204/13204?

\section{Can a nonsignatory be estopped from disclaiming the obligation to arbitrate?}

Even when one party to a multiparty dispute did not sign an arbitration agreement, courts have, on rare occasion, compelled a nonsignatory to arbitrate under the doctrine of estoppel. In the arbitration context, this doctrine generally requires a signatory to arbitrate (and not disclaim an obligation to arbitrate) claims with a nonsignatory when the nonsignatory's claims are "inextricably intertwined" with the agreement signed by the signatory.

The Eighth Circuit considered this doctrine in the context of a raiding dispute between Bank of America, N.A. ("BOA"), not a FINRA member, and UMB Financial Services, Inc. ("UMB"), a FINRA member. ${ }^{81}$ Soon after five former BOA employees (financial advisors who brokered securities through Banc of America Investment Services ("BOAIS")) joined UMB, BOA sued its former employees and UMB in federal court in Missouri alleging violations of the employees' non-solicitation agreements.

In addition to pursuing various procedural maneuvers in the district court, UMB filed a FINRA arbitration claim against both BOA and BOAIS. ${ }^{82}$ BOA refused to arbitrate against UMB, on the grounds that, unlike BOAIS and UMB, it is not a FINRA member. The district court denied UMB's motion to compel arbitration and enjoined the parties from arbitrating pending

\footnotetext{
${ }^{80}$ See Howsam v. Dean Witter Reynolds, Inc., 537 U.S. 79 (2002).

${ }^{81}$ Bank of America, N.A. v. UMB Financial Services, Inc., 618 F.3d 906 $\left(8^{\text {th }}\right.$ Cir. 2010).

${ }^{82}$ Id. at 909.
} 
resolution of various issues before the district court. After further proceedings, the district court granted BOA's motion for a preliminary injunction, restraining three of its former employees from further violating their active non-solicitation agreements, and restraining UMB from doing business with customers obtained in violation of those agreements. ${ }^{83}$

UMB and the former employees appealed, arguing that the district court erred in refusing to compel BOA and BOAIS to arbitrate before FINRA. UMB argued that BOA should be estopped from disclaiming the obligation to arbitrate because its claims are "inextricably intertwined with any claims BOAIS might bring against the appellants and because BOA seeks to benefit from its association with BOAIS." 84 The Eighth Circuit rejected the estoppel argument, because, unlike the typical estoppel scenario, the nonsignatory here is not the party pursuing arbitration. The appellate court further held that BOA is not a third party beneficiary of BOAIS' arbitration agreements (Forms U-4) with the BOA former employees. ${ }^{85}$ Thus, the Court of Appeals affirmed the district court's refusal to compel BOA to arbitrate.

Estoppel remains a valid exception to the requirement of an arbitration agreement, but courts typically limit its use to the situation where a nonsignatory seeks to compel a signatory to arbitrate claims inextricably intertwined with an arbitration agreement. Signatories cannot draw in nonsignatories to an arbitration simply because the claims are related; nonsignatories have to indicate a willingness to arbitrate.

\footnotetext{
${ }^{83} \mathrm{Id}$. at 910.

${ }^{84} \mathrm{Id}$. at 912.

${ }^{85}$ Id. at 913 .
} 


\section{B. Res Judicata Effect of Arbitral Award}

The First Circuit, in FleetBoston Financial Corp. v. Alt, ${ }^{86}$ recently considered the res judicata effect of an arbitral award. The dispute arose out of employment claims of Eric Alt (lead claimant) and forty-one additional former employees of the brokerdealer Robertson Stephens, Inc. (RSI). Claimants alleged various theories of liability and sought over $\$ 140$ million in damages from Respondents RSI, RSI's owner, Robertson Stephens Group, Inc. (RSGI), and RSGI's owner, FleetBoston Financial Corporation (Fleet). Arbitration hearings which lasted more than two years resulted in an award to twenty-seven claimants of over $\$ 14$ million. ${ }^{87}$

While the arbitration was in progress, RSI, RSGI and Fleet filed an action in Massachusetts state court against the Alt claimants seeking a declaratory judgment and a stay of the arbitration as to RSGI and Fleet, claiming they were not members of the NYSE and did not agree to arbitrate. ${ }^{88}$ After removal, the district court for the District of Massachusetts declined the stay request, choosing to stay its own proceeding pending the result of the arbitration. ${ }^{89}$

Following the award, both claimants and respondents sought to remove the stay, which resulted in the district court confirming the arbitral award. ${ }^{90}$ The Alt claimants also amended their initial counterclaim to add claims related to deferred compensation in the form of a cash equivalent plan (CEP) and a restricted stock unit plan (RSU). Claimants contended the CEP and RSU claims were both unresolved and could be brought

${ }^{86} 638$ F.3d 70 (1st Cir. 2011).

${ }^{87}$ Id. at 72 .

${ }^{88}$ Id. at 74 .

${ }^{89} \mathrm{Id}$.

${ }^{90}$ Id. at 75 . 
against RSGI and Fleet in a new action. ${ }^{91}$ Fleet and RSGI moved for summary judgment on the grounds these claims were included in the arbitral award and " "barred as a matter of law by reason of claim preclusion, judicial estoppel, invited error, and payment.",92 The district court granted the motion, and the Alt claimants appealed.

The First Circuit affirmed the district court's finding that the arbitral award included the CEP and RSU claims. The Court of Appeals noted that "[a]n arbitration award generally has res judicata effect as to all claims heard by the arbitrators." ${ }^{93}$ The Court concluded, "[i]n light of the manner in which Alt presented the RSU and CEP claims in its Amended Statement of Claims, the evidence Alt presented to the panel, and the arbitral award itself, it is most reasonable to interpret the award's scope -'all of the claims between the parties' - to include all of Alt's CEP and RSU claims." $" 94$

Applying the doctrine of res judicata to arbitration awards serves the same purpose as in judicial proceedings - it prevents costly re-litigation of the same issues and provides closure. Because the Alt claimants took advantage of the opportunity to litigate their claims during arbitration, the court saw no unfairness in its decision. ${ }^{95}$

${ }^{91} I d$.

${ }^{92} \mathrm{Id}$. at 75 (internal quotation omitted).

${ }^{93} \mathrm{Id}$. at 79 (internal quotation omitted).

${ }^{94} \mathrm{Id}$. at 76-77 (citation omitted).

${ }^{95} \mathrm{Id}$. at 81 . 


\section{Post-Award Review}

\section{Arbitrator Bias}

The Seventh Circuit recently considered whether an arbitrator's "reputational interest" in being appointed again impacts his neutrality. In Trustmark Insurance Co. v. Hancock Life Insurance Co. ${ }^{96}$ Hancock Life Insurance Co. ("Hancock") and Trustmark Insurance Co. ("Trustmark") executed a reinsurance contract which included a pre-dispute arbitration clause calling for a tripartite arbitration panel. ${ }^{97}$ Hancock appointed Mark Gurevitz as its party arbitrator.

After Trustmark lost the arbitration and Hancock confirmed the award in U.S. District Court in Illinois, Trustmark refused to honor retrocessional reinsurance contract billings involved in the first arbitration that were due to Hancock based on the award. ${ }^{98}$ Trustmark argued that the confirmed award governed all of the parties' dealings, and thus any billings subsequent to the award were not valid. ${ }^{99}$

After initiating a new arbitration to resolve the subsequent disputed bills, Hancock named Gurevitz as its party-appointed arbitrator once again. Hancock argued that the prior award should be dispositive in the new dispute, but Trustmark contended that the second panel should not consider the first award at all due to the existence of a confidentiality agreement reached during the first proceeding. The second panel ruled that the confidentiality

\footnotetext{
96631 F.3d 869 (7th Cir. 2011).

${ }^{97}$ On a tripartite panel, each party appoints one arbitrator, and then those two party-appointed arbitrators appoint the third arbitrator, who is presumed to be neutral.

${ }^{98}$ See Trustmark Ins. Co. v. John Hancock Life Ins. Co., 680 F. Supp. 2d 944, 945 (N.D. Ill. 2010).

${ }^{99}$ See Trustmark, 631 F.3d at 871 .
} 
agreement did not preclude the arbitrators themselves from considering the prior award. ${ }^{100}$

Before substantive hearings took place, Trustmark sought an injunction in the district court, arguing that Gurevitz was not a "disinterested" arbitrator as required by the arbitration agreement's appointment procedures. The district court ruled that Gurevitz was not "disinterested" due to his knowledge of the prior arbitration and the fact that he could be called as a fact witness about those proceedings.

The Seventh Circuit reversed, holding that the term "disinterested" in the context of an adjudication means "lacking a financial or other personal stake in the outcome." "101 The court found that Gurevitz did not, in fact, have any stake in the outcome of the arbitration beyond a "reputational interest" - the incentive to rule in favor of the party that appointed him to make it more likely to be appointed by that party in a future arbitration. ${ }^{102}$ Because potential future employment is an interest that is "endemic to arbitration," arbitrators cannot be dismissed on the ground that they may be inclined to support the party that appointed them. ${ }^{103}$ Rather, " $[w]$ hen one party is entitled to choose its own arbitrator, and in doing so follows all contractual requirements, a court ought not abet the other side's strategy to eject its opponent's choice."104

Because FINRA arbitrators also have a reputational interest in being appointed by repeat players in securities arbitrations, this case impacts the ability of claimants to argue that

\footnotetext{
${ }^{100} \mathrm{Id}$. at 871 .

${ }^{101} \mathrm{Id}$. at 872 .

${ }^{102}$ Id.

${ }^{103}$ Id. (citing Sphere Drake Insurance Ltd. V. All American Life Insurance Co., 307 F.3d 617, 622 (7th Cir. 2002)).

${ }^{104}$ Id. at $873-74$.
} 
arbitrators selected and favored by broker-dealers or brokers are not neutral.

In addition to arbitrator neutrality requirements set forth in parties' arbitration agreements and/or forum rules, the FAA authorizes a court to vacate an arbitration award, inter alia, "where there was evident partiality ...in the arbitrators...,"105 or for "other misbehavior [by arbitrators] by which the rights of any party have been prejudiced." ${ }^{106}$ Just as this chapter went to press, the Second Circuit handed down a decision interpreting these sections in the context of a FINRA arbitration award. In STMicroelectronics, N.V. v. Credit Suisse Securities (USA), LLC, ${ }^{107}$ Credit Suisse moved to vacate an award against it for more than $\$ 400$ million arising out of its sale of auction-rate securities ("ARS") to STMicroelectronics ("ST"), a semiconductor manufacturer, whose cyclical business required it to keep a lot of cash or cash equivalents on hand to meet its needs. When the ARS market froze in August 2007, the ARS owned by ST failed at auction, rendering them significantly lower in value. ${ }^{108}$

ST filed a FINRA arbitration claim against Credit Suisse in February 2008 alleging, inter alia, federal securities fraud, common law fraud, breach of contract, breach of fiduciary duty, and failure to supervise. During the arbitration, Credit Suisse unsuccessfully sought to remove one of the arbitrators, who often testified as a financial expert, for purportedly failing to disclose details about his prior testimony on behalf of investor-claimants. After the arbitration panel awarded ST more than $\$ 400$ million in compensatory damages, financing fees, attorneys' fees and interest, Credit Suisse moved to vacate the award on the grounds

\footnotetext{
1059 U.S. C. $\S 10(a)(2)$.

1069 U.S. C. $\S 10(a)(3)$.

${ }^{107}$ Docket No. 10-3847-cv (2d Cir. June 2, 2011).

${ }^{108} \mathrm{Id}$. at $3-5$.
} 
of "evident partiality," arbitrator "misbehavior," and "manifest disregard of the law." 109

The district court (SDNY) refused to vacate the award, and also refused to partially offset the award by just under $\$ 75$ million following ST's post-arbitration sale of the ARS to a third party.

On appeal, the Second Circuit affirmed the district court with respect to the award vacatur, except modified the amount of the compensatory damages to account for the $\$ 75$ million offset and corresponding interest. On the issue of arbitrator bias, the Court of Appeals noted that Credit Suisse had rightly abandoned its arguments under the evident partiality prong of the FAA, because it could not meet the very high burden of showing a failure to disclose facts demonstrating partiality, which the court defined as a "relationship with a party, a lawyer or another arbitrator." Rather, Credit Suisse alleged only that the arbitrator had an unfavorable "predisposition."110

The court then rejected Credit Suisse's contention that the arbitrator's disclosure report was misleading in violation of FINRA rules. Notably, the appellate court faulted Credit Suisse for not having taken discovery on the issue of the arbitrator's background, which Second Circuit precedent would have permitted. ${ }^{111}$ The fact that the arbitrator's disclosures complied with FINRA's own written "explication" of its disclosure requirements persuaded the appellate court further that the arbitrator had not engaged in "other misbehavior" within the

\footnotetext{
${ }^{109}$ STMicroelectronics, at 5-8. See infra § II.C.2 for a discussion of the continued validity of the "manifest disregard of the law" standard of review.

${ }^{110} I d$. at 10 (emphasis in original).

${ }^{111} I d$. at 12 ("Although we have limited the availability of discovery regarding the completeness of an arbitrator's disclosure, we have not forbidden it altogether.").
} 
meaning of section 10(a)(3). ${ }^{112}$ The court concluded that the arbitrator's alleged predisposition on issues of law could not be the basis for vacatur because, as the industry arbitrator, his prior testimony on and expertise with related issues of law is precisely what qualifies him to be an industry arbitrator. ${ }^{113}$

The Court of Appeals then addressed Credit Suisse's second argument for vacatur: that the panel must have manifestly disregarded the law ${ }^{114}$ applicable to ST's fraud claim because it did not enforce against ST the clause in the parties' agreement requiring ST to object to trade confirmations within two days and account statements within ten days, ${ }^{115}$ and because it ignored the "reasonable reliance" element of fraud. The Second Circuit soundly rejected this alternative vacatur ground, reasoning that: (1) the Modern Settings defense is not a "well-defined, explicit, and clearly applicable" rule as required by the first prong of the manifest disregard standard; (2) because the element of "reasonable reliance" requires an inherently fact-specific analysis, and Credit Suisse cited all factually distinguishable precedent, Credit Suisse could not show that the panel disregarded factually analogous precedent; and (3) even if the panel had disregarded these valid defenses to ST's fraud claim, the award did not contain reasons, so the entire award could have been based on one of ST's non-fraud claims. ${ }^{116}$ Finally, the Second Circuit reduced the award by $\$ 75$ million - the amount ST received from the liquidation of its

${ }^{112} I d$. at 14 .

${ }^{113} \mathrm{Id}$. at $16-17$.

${ }^{114}$ The continued vitality of the "manifest disregard of the law" standard of vacatur is discussed infra, section II.C.2.

${ }^{115}$ According to Credit Suisse, this disregarded the rule set forth in Modern Settings, Inc. v. Prudential-Bache Securities, Inc., 936 F.2d 640 (2d Cir. 1991).

${ }^{116}$ STMicroelectronics, at 17-25. 
ARS, plus the corresponding amount of interest due on that money. ${ }^{117}$

Perhaps the most interesting aspect of the Second Circuit's opinion, particularly to securities arbitration aficionados, is its hostility to Credit Suisse for trying to avoid some of the consequences of the very arbitration process it imposed on its customer:

We note again that Credit Suisse could have chosen to permit its customers to resolve disputes in the courts, where legal issues such as these could be authoritatively resolved. It deliberately chose, however, to insist on a forum in which issues are resolved less formally, without the necessity for the adjudicator to explain its precise reasoning or the availability of appellate tribunals to review and assess that reasoning. Having chosen that process, with its attendant expedition and lower cost, Credit Suisse may not now impose on its adversary the very formalities it elected to eschew, simply because it does not like the outcome of the process.

Ouch!

${ }^{117} I d$. at $25-28$.

${ }^{118} I d$. at 21 n.6. 


\section{Manifest Disregard of the Law}

Since the Supreme Court's holding in Hall St. Assoc., L.L.C. $v$. Mattel, Inc. ${ }^{119}$ that parties to an arbitration agreement cannot contractually expand the judicial grounds of review of an award under the FAA, the lower courts have split on whether an arbitration panel's "manifest disregard of the law" is a valid ground to vacate an arbitration award. The Supreme Court expressly declined to resolve this split in Stolt-Nielsen S.A. v. AnimalFeeds Int'l Corp. ${ }^{120}$ Since last year's Arbitration Law Update, the circuit split continues:

- The Second, Sixth, and Ninth Circuits have acknowledged the continued vitality of the "manifest disregard" ground of vacatur. ${ }^{121}$

- The Fifth and Eleventh Circuits have expressly determined that manifest disregard is no longer a valid vacatur ground. ${ }^{122}$

- The First and Eighth Circuits have addressed "manifest disregard" subsequent to Hall Street, but only in dicta. ${ }^{123}$

\footnotetext{
119552 U.S. 576 (2008).

${ }^{120} 130$ S. Ct. 1758,1768 n.3 (2010).

${ }^{121}$ See Stolt-Nielsen S.A. v. AnimalFeeds Int'1 Corp., 548 F.3d 85, 94 (2d Cir. 2008), vacated on other grounds, 130 S. Ct. 1758 (2010); Coffee Beanery, Ltd. v. WW, L.L.C., 300 Fed.Appx. 415, 419 (6th Cir. 2008); Comedy Club, Inc. v. Improv West Assocs., 553 F.3d 1277, 1290 (9th Cir. 2009).

${ }^{122}$ See Citigroup Global Markets, Inc. v. Bacon, 562 F.3d 349, 352 (5th Cir. 2009); Frazier v. CitiFinancial Corp., 604 F.3d 1313, 1324 (11th Cir. 2010).

${ }^{123}$ See Kashner Davidson Secs. Corp. v. Mscisz, 601 F.3d 19, 21 (1st Cir. 2010) (acknowledging that the circuit has "not squarely determined whether our manifest disregard case law can be reconciled with Hall Street"); Crawford Group, Inc. v. Holekamp, 543 F.3d 971, 976 (8th Cir. 2008).
} 
- The Third, Fourth and Tenth Circuits have expressly declined to address the issue. ${ }^{124}$

\section{Exceeding Powers}

While the confusion over the "manifest disregard" ground of review persists, losing parties in arbitration continue to challenge arbitration awards on grounds specified in the FAA. In Merrill Lynch, Pierce, Fenner \& Smith, Inc. v. Whitney, ${ }^{125}$ the Tenth Circuit considered whether an arbitration panel exceeded its powers under FAA $\S 10(a)(4)$ in interpreting the terms of a contract, when it considered whether someone possessed the legal authority to assign beneficiaries to an account, and when it awarded legal fees to the Appellee.

The dispute between the parties stemmed from two accounts that were opened by the Appellant's sister, Suzanne, following the death of their mother. Suzanne decided to have her $50 \%$ share of their mother's two IRA accounts placed into two beneficiary-controlled accounts with the Appellee bank, Merrill Lynch. When opening the accounts, Suzanne was required to fill out a standard "Merrill Lynch Client Relation Agreement (CRA)," which was used to specify the type of account and assign beneficiaries. When filling out the agreement, Suzanne assigned two beneficiaries to the first account, while assigning none to the second.

Following Suzanne's death, the Appellant asserted that under the CRA and Oklahoma law, the second account which was

${ }^{124}$ See Paul Green School of Rock Music Franchising, LLC v. Smith, 389 Fed. Appx. 172, 176 (3d Cir. 2010); Raymond James Fin. Servs., Inc. v. Bishop, 596 F.3d 183, 193, n.13 (4th Cir. 2010); Legacy Trading Co. v. Hoffman, 2010 WL 325893, at *2 n.2 (10th Cir. Jan. 29, 2010) (slip op.). ${ }^{125}$ No. 10-5072, 2011 U.S. App. LEXIS 7041 (10th Cir. Apr. 4, 2011). 
assigned no beneficiaries belonged to their mother's estate, and should revert to her heirs, which was the Appellant. ${ }^{126}$ During arbitration, the panel relied on a format flaw contained in the CRA, and determined that this flaw was the reason no beneficiaries were named to the second account. Based on this determination, the Tenth Circuit affirmed the district court's ruling that the panel did not exceed its power in making a factual determination that Suzanne intended for the beneficiaries named in account one to also be assigned to account two. ${ }^{127}$

Appellant also argued that Suzanne never had legal authority to name beneficiaries to either of the accounts, because "when Suzanne inherited IRA accounts from her mother, she elected to retain her 'beneficiary' status and not become the 'owner' of the accounts."128 Based on this assertion, the Appellant contended that Internal Revenue Service regulations forbid Suzanne from assigning beneficiaries to the accounts, as this right was reserved to the true owner, which was their mother. The panel disagreed, and instead relied on an expert witness' testimony that an IRA becomes the account of a designated beneficiary upon the death of its owner. Thus, Suzanne became the owner of her share of the IRA, and was free to assign beneficiaries at her will. As a result, the Tenth Circuit affirmed the district court's ruling that the panel did not exceed its powers in making this determination. $^{129}$

Finally, the Appellant argued that the panel exceeded its power in awarding legal fees to the Appellee in the absence of supporting detail, purportedly required by Oklahoma law. However, because the district court had identified Oklahoma precedent which provided an exception to the documentation

\footnotetext{
${ }^{126} I d$. at $* 5$.

${ }^{127}$ Id. at $* 19$.

${ }^{128}$ Id. at $* 6$.

${ }^{129}$ Id. at $* 23$.
} 
requirement, the Tenth Circuit affirmed the district court's conclusion that the arbitration panel was not acting "arbitrary, capricious, whimsical, or manifestly unreasonable" in awarding fees and costs to the Appellee. ${ }^{130}$

\section{A Few Notable State Court Decisions}

\section{A. Statutes of Limitation}

Securities arbitration practitioners are routinely faced with the question of whether statutes of limitation are applicable in arbitration. This past year, a Florida court joined the growing number of jurisdictions that have held that statutes of limitation apply to actions in court, but not arbitrations. In Phillips $\boldsymbol{v}$.

Raymond James Financial Services, Inc. ${ }^{131}$ the court was tasked with determining the timeliness of arbitration claims for negligence and breach of fiduciary duty (based on suitability and failure to supervise claims), as well as statutory fraud under Florida's securities statute. ${ }^{132}$ Following a Florida Supreme Court 1995 precedent, ${ }^{133}$ the circuit court determined that Florida statutes of limitation do not apply to FINRA arbitration.

\section{B. Confidentiality}

In Dever v. Oppenheimer \& Co., Inc., ${ }^{134}$ a Massachusetts Superior Court overturned a confidentiality order imposed by a FINRA arbitration panel on First Amendment grounds. Claimant

${ }^{130} I d$. at $* 7$.

${ }^{131}$ Case No. 07-0080-CA (Fla. Cir. Ct. Apr. 9, 2010).

${ }^{132}$ Before proceeding with a potentially unnecessary evidentiary hearing, the parties submitted the case to the Circuit Court for a ruling on the applicability of the Florida statutes of limitation to the arbitration claims. ${ }^{133}$ Meile v. Prudential-Bache, Inc., 656 So.2d 470 (Fla. 1995).

${ }^{134}$ No. SUCV2009-05051, Docket no. 19 (Mass. Sup. Ct. June 28, 2010) (Bloomberg Law) (2010 SECURITIES ARBITRATION COMMENTATOR 3 (Apr. 2011). 
James Dever contended that the FINRA gag order, which required confidential treatment of all details of the twenty-day hearing's testimony, documents and hearing transcripts, restricted him from clearing his reputation which allegedly had been tarred by the disclosures included on his Form U-5.

Parties to arbitration commonly enter into confidentiality agreements either in their arbitration clauses or during the discovery phase of the dispute. ${ }^{135}$ Although gag orders that bar parties from discussing a case while it is pending are not uncommon, Dever argued that a broad order imposing confidentiality after the case is heard is unprecedented. For example, the Seventh Circuit, in Citizens First Nat'l Bankv. Cincinnati Ins. Co. ${ }^{136}$ required "good cause" before sealing documents and presumed public access to those materials that did not meet this requirement. The Court of Appeals suggested that courts have begun to resist "standardless, stipulated, permanent, frozen [and] overbroad blanket [confidentiality] order[s]."137

In Dever, Judge McIntyre stated that members of FINRA forums do not expect their proceedings to be cloaked in secrecy, and that arbitrators should not be able to conceal the proceedings under broad confidentiality orders. Such orders, under McIntyre's analysis, offend free speech protection under the First Amendment.

${ }^{135}$ In fact, FINRA encourages arbitrators to suggest confidentiality stipulations or to enter confidentiality orders to facilitate discovery. The FINRA Discovery Guide provides that, "[i]f a party objects to document production on grounds of privacy or confidentiality, the arbitrator(s) or one of the parties may suggest a stipulation between the parties that the document(s) in question will not be disclosed or used in any manner outside of the arbitration of the particular case, or the arbitrator(s) may issue a confidentiality order." FINRA Discovery Guide, at 2.

136178 F.3d 943 (7th Cir. 1999).

${ }^{137} \mathrm{Id}$. at 946 . 
This decision made clear that courts will not blindly enforce confidentiality orders, but will examine them to determine if they unlawfully restrict the constitutional rights of the parties involved. It will be interesting to see how other courts begin treating confidentiality orders, and whether they adopt Judge McIntyre's analysis.

\section{Post-Award Review}

While the federal circuits are split as to whether manifest disregard of the law is a valid basis of vacatur (see supra, § II.D), some state courts still recognize that standard of review. In

Wiederhorn v. Merkin, a New York Supreme Court judge applied the manifest disregard standard to a challenge to a $\$ 1.75$ million award arising out of a Madoff-related dispute. ${ }^{138}$

When Claimant moved to confirm the award, Respondent cross-moved to vacate the award on the grounds that the findings were "totally irrational" and in manifest disregard of the law. ${ }^{139}$ The court acknowledged that New York courts recognize the FAA's manifest disregard provision, but severely limit the doctrine by restricting its application to situations of "last resort limited to the rare occurrences of apparent 'egregious impropriety' on the part of the arbitrators, 'where none of the provisions of the FAA

${ }^{138}$ See Wiederhorn v. Merkin, 601265/2010, NYLJ, at *2 (Sup. Ct. N.Y. Co. Aug 6, 2010). Respondent J. Ezra Merkin was the General and Managing Partner of Ascot Partners, L.P. ("Ascot"), a private investment partnership for U.S. investors. Petitioner Noel M. Wiederhorn ("Wiederhorn") owned a Delaware IRA which invested a total of \$1,492,040.47 in Ascot, and Ascot subsequently invested "substantially all" of its assets in an account with Bernard L. Madoff Investment Securities. Id. Madoff's Ponzi scheme "rendered the value of Ascot virtually worthless," thus losing "substantially all" of Widerhorn's investment in Ascot. Id.

${ }^{139}$ Id. at $* 5$. 
apply." "140 This extreme deference to the arbitrators' decision will be overcome only if the party moving for vacatur shows that: (1) the arbitrators had known of a governing legal principle; (2) they refused to apply or altogether ignored that principle; and (3) the ignored law was well-defined, explicit, and clearly applicable to the case at hand. ${ }^{141}$

In the case at hand, the court concluded that, due to a split in the Appellate Divisions within New York State on the applicable point of law, it could not find the arbitrators manifestly disregarded the law because the third element's "well-defined" requirement could not be satisfied. Significantly for securities arbitration practitioners, the court also upheld the arbitrators' freedom to apply principles of equity and their own sense of the law when rendering an award. In Wiederhorn, the majority of the tribunal stated clearly in its award that it based many of its decisions on principles of equity. As a result, the trial court denied the motion for vacatur and confirmed the award.

${ }^{140} I d$. at *6.

${ }^{141} I d$. 